\title{
Place-Based Sustainability Planning: Implications \& Recommendations for Rural Northwestern Ontario
}

\author{
Rebecca Schiff \\ Lakehead University
}

\begin{abstract}
As rural regions in Northwestern Ontario are faced with dynamic changes, it is important they are equipped with the tools and strategies needed to maintain healthy environments, resilient communities, and robust economies. There is a need for innovative approaches to rural planning that incorporate the values and tools of sustainability planning and, as such, will be more equipped to address the diverse strengths and challenges of rural regions. This article attempts to identify the potential for place-based and northern adaptations of sustainability planning. It highlights challenges for sustainability planning in rural areas and discusses how smart growth approaches have the potential to guide planning processes in rural locales. It then examines an existing rural smart growth framework and gaps in that framework from a northern perspective. The article concludes with some proposed adaptations to the rural smart growth framework to address the unique characteristics and needs of northern, rural communities and regions; adaptations that might help to further development of regional, place-based, sustainability planning in Northwestern Ontario and across Canada's Provincial North.
\end{abstract}




\section{Introduction}

As rural regions in Northwestern Ontario are faced with dynamic changes, it is important they are equipped with the tools and strategies needed to maintain healthy environments, resilient communities, and robust economies. Rural and remote towns and regions ${ }^{1}$ are as diverse as urban areas, and critical to ecological and social well-being, yet they are not studied as extensively as their urban counterparts (AAMDC, 2008; Mayer \& Knox, 2010). Rural and remote communities have their own diverse needs, challenges, interests, and opportunities and it is important that rural and regional planning reflects this diversity (Daniels et al., 2007; Scott et al., 2000). There is a need for innovative approaches to rural planning that incorporate the values and tools of sustainability planning and, as such, will be more equipped to address the diverse strengths and challenges of rural regions (Hahn, 1970; Ryan-Nicholls, 2004).

This article attempts to identify the potential for northern adaptations of smart growth frameworks that could help to address regional sustainability planning needs in Northwestern Ontario. The article begins with a discussion of the context of Northwestern Ontario, sustainability challenges in the region, and regional planning history. It then examines the dominant discourse on sustainability planning, which tends to be urban-centric and often lacks focus on rural sustainability planning needs. This leads to an overview of some of the literature on rural and place-based adaptations of urban sustainability planning approaches. In particular, the

article examines an existing framework that provides a rural adaptation of smart growth $^{2}$ principles. The article then discusses gaps in this framework from a northern perspective. It concludes with suggested adaptations to this framework in order to further development of regional, place-based, sustainability planning in rural Northwestern Ontario and in rural regions across Canada's Provincial North.

\section{The Context: Northwestern Ontario and Challenges to Regional and Rural Sustainability}

Although Northern Ontario makes up 90\% of Ontario's total land mass, 2016 Census data indicate that it is home to only about $5.8 \%$ of the population of Ontario (Statistics Canada, 2017a, 2017b). 


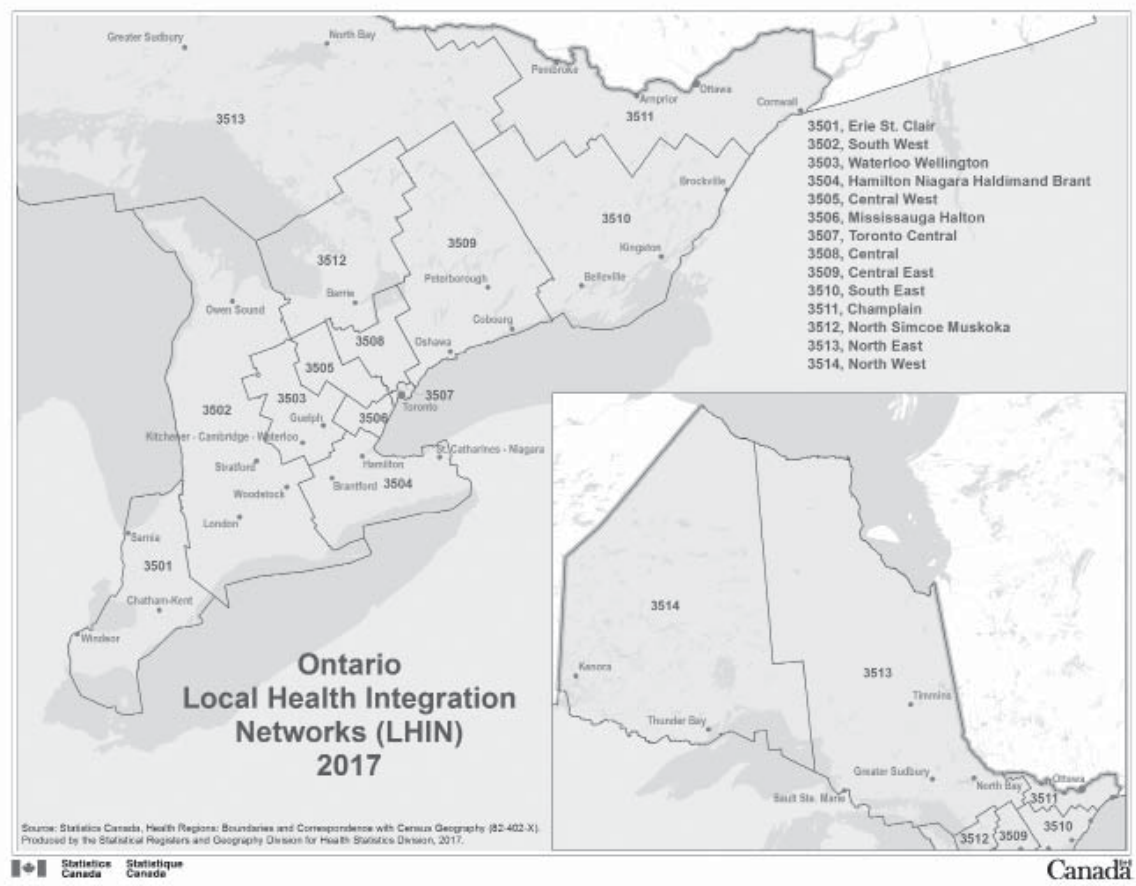

Figure I: Map of Ontario illustrating geographic regions as defined according to Local Health Integration Network boundaries (Statistics Canada, 20I7c)

Northwestern Ontario, a sub-region of Northern Ontario, is unique and differs from its Northeast counterpart. In particular, it is slightly larger in land mass than the Northeast although has less than half the population. Northwestern Ontario is comprised of three districts: Kenora, Rainy River, and Thunder Bay (Beaulieu \& Southcott, 2010; Rody, 2016; Woodrow, 2002). The region is bordered by Manitoba, the Hudson Bay coastline, the James Bay coastline, the north shore of Lake Superior, and the American border (Beaulieu \& Southcott, 2010). Approximately 231,700 persons live in this region of Ontario that covers approximately $526,480 \mathrm{~km}^{2}$ (Statistics Canada, 2017a). The region saw several decades of population decline although the most recent census demonstrated a 3.4\% increase in the population. Roughly $50 \%$ of the population resides in Northwestern Ontario's largest city, Thunder Bay (Immigration Northwestern Ontario, n.d). This city is the industrial, commercial, and medical centre of Northwestern Ontario (Immigration Northwestern Ontario, n.d). The 
second largest city in Northwestern Ontario, Kenora, has a population of roughly 15,100 (Statistics Canada, 2017a).

Northwestern Ontario is home to a large population of Indigenous peoples. Approximately $25 \%$ of the total population identifies as Indigenous (Statistics Canada, 2017a) compared to Ontario and national averages of $2.8 \%$ and $4.9 \%$ respectively (Statistics Canada 2017d, 2017e). Other major ethnic groups include English, Scottish, French, Italian, Portuguese, and Scandinavian (Immigration Northwestern Ontario, n.d). There are many First Nations and smaller rural communities located throughout the region (Beaulieu \& Southcott, 2010). Tourism in Northwestern Ontario is nature-based and the abundance of lakes and land provides plenty of opportunities for outdoor recreation such as hunting and fishing (Beaulieu \& Southcott, 2010). Export industries including mining, transportation, manufacturing, and transportation services have driven economic growth and created employment opportunities in the region (Ontario Chamber of Commerce, 2016).

Northern Ontario is particularly unique as a region, when compared to its southern counterparts, for the predominance of towns dependent on a single resource or industry (usually forestry or mining related) and as home to a large number of remote First Nations. These characteristics create distinct challenges, strengths, and needs in terms of local and regional planning.

\section{Rural Sustainability Challenges in Northwestern Ontario}

There are several environmental, economic, and social challenges that compromise the sustainability of rural communities and regions in Northwestern Ontario. Communities in Northwestern Ontario have benefited economically (due to increased employment and private sector investment) from a richness of natural resources and various associated industries; however these industries have also led to environmental pressures (such as water, air, and land pollution due to pulp and paper milling) and economic challenges, particularly when they have reduced or closed operations in the region. The impact of changing economic conditions in smaller communities is greater than in larger communities (EPA, 2016). Smaller communities are more likely to have difficulties transitioning and adjusting following challenges within a single economic sector (Hodge, Hall, \& Robinson, 2017). They lack the political, cultural, and economic 
resources to address changing circumstances (Beaulieu \& Southcott, 2010). Rural communities in Northwestern Ontario have faced difficulties adapting to the post-industrial economy ${ }^{3}$ (Beaulieu \& Southcott, 2010). The introduction of new technologies and the decline of industrialism has negatively impacted many communities, particularly through declines in employment opportunities and private sector investment in small and single resource-dependent communities (Beaulieu \& Southcott, 2010).

Another challenge that has impacted rural communities in Northwestern Ontario is rural-urban migration. Across rural Canada, difficulties with workplace recruitment and retention (CMHA, 2009) along with limited employment and educational opportunities, frequently spur rural-urban migration to nearby cities (CPHI, 2006). In Northern Ontario, the closure or challenges within various industries, and particularly in the mining industry, have led to a shrinking job base and migration to larger urban centres for other economic opportunities (Mitchell \& O'Neill,2016; Woodrow, 2002). This migration creates further challenges. As Canada has transitioned from a rural to an urban society, political power has shifted away from rural communities and towards urban centres (Caldwell et al., 2013). As Caldwell et al. (2013) discuss, this has negatively impacted financial and resource support and assistance to rural regions from higher levels of government.

Rural to urban transitions and changes to in-migration patterns have also led to shifting demographics in rural Northwestern Ontario. Smaller communities in Northern Ontario are aging at a rapid pace in comparison to their urban counterparts (CRRF, 2015; OPPI, 2009). This shift in population demographics requires careful planning to ensure that communities are properly prepared with adequate and appropriate housing, services, transportation, and other needs that change with ageing populations (Caldwell et al., 2013). It is important that communities appropriately plan for upcoming changes through the implementation of inclusive and equitable policies that account for diverse demographics, so that they can prepare and meet the diverse needs of their residents.

Rural communities in Northwestern Ontario also must confront the many serious and ubiquitous global environmental issues. Climate change is an increasingly urgent concern that communities and regions must consider in their planning activities (Canadian Institute of Planners, 2018). The Government of Ontario has recognized that Northern Ontario 
is feeling the impacts of climate change much sooner and more acutely than southern Ontario (Ministry of the Environment, Conservation and Parks, 2018). Northwestern Ontario also faces serious concerns that are specific to the region. In addition to climate change, Environment North (2019) identifies several areas of significant environmental concern for the region including impacts of forestry and mining, nuclear waste, and community resilience to environmental change.

Given the various economic, social, and environmental concerns that threaten sustainability in Northwestern Ontario, it is clear that there is a need for innovative strategies and strategic planning. Placebased sustainability planning has the potential to transform regional rural planning and to help smaller communities navigate ongoing social, environmental, and economic changes (Alexander and Jones, 2016; EPA, 2016).

\section{Urban Centrism and Place-Based Sustainability Planning for Rural Regions}

Too often, discourse around sustainability planning focuses solely on urban environments, or otherwise places urban centres at the core of planning with peripheral consideration of rural and northern planning needs (Daniels et al., 2007; Edwards \& Haines, 2007; Hodge, Hall, \& Robinson, 2017; Maye \& Knox, 2010). The planning needs of very small towns and counties or municipalities are often completely unmet due to lack of local resources or support from larger centres. Most often it is larger towns that are able to take advantage of opportunities for rural sustainability planning; when regional planning occurs, it is often driven by actors in those larger centres with the resource base to support planning efforts. ${ }^{4}$ Indeed, it was larger and well-resourced municipalities and regions that were able to take advantage of the "Green municipal funds" to support sustainability planning in the federal government's 2005 "New Deal for Canadian Cities and Communities," while less-resourced regions were often subject to frameworks imposed by urban-centric policies created at provincial and federal levels (Hallstrom 2016; Grant, Beed, \& Manuel 2018).

Similarly, the Government of Ontario has introduced several attempts to support northern and regional planning. This includes the Northwestern Smart Growth Panel, which operated between 2002 and 2003 as one of five regional panels, and which produced a final report to 
provide direction for smart growth in the region. Attempts also include the more recent "Growth Plan for Northern Ontario" introduced in 2011 by the provincial government through the Ministry of Infrastructure and Ministry of Northern Development, Mines, and Forestry (Government of Ontario, 2011). Although framed through smart growth principles, the final recommendations of both the panel (Nelson, 2012) and the growth plan remained urban-centric; for example, the "government investment" described in the 2011 growth plan focuses primarily on investments in urban communities, major infrastructure (highways), and resource development sectors, as well as some minor investments in First Nations. The plan explicitly focused on "economic and service hubs of the North," and mostly on the five major urban centres, with little mention of investment in or support for that smaller, rural towns or townships that make up half of the population of Northern Ontario. This may be due in part to the fact that development of the panel report and growth plan involved leadership from primarily municipal-based elected officials, with limited consultation and input from rural residents and planners. For these reasons, both the panel report and the growth plan failed to respond to the needs of a predominantly rural region. As the president and CEO of Ontario's Northern Policy Institute suggests, the government may need to rethink its approach to regional development and more clearly embrace the economic, social, and ecological diversity that exists across northern Ontario (Cirtwell, 2017).

In 2002 Woodrow (2002) also produced a report for the environmental commissioner on sustainability challenges in Northern Ontario. Although not specifically aimed at regional planning, Woodrow's report provides a useful counterpoint to the growth panel report and the 2011 growth plan, with more focus on the strengths, values, and needs of smaller rural communities.

For decades, planners have been criticized for establishing planning praxis and related policy that is driven by urban actors and urban experiences (Edwards \& Haines, 2007; Hahn, 1970). Due to fundamental differences across environmental, social, economic, and cultural domains, it is not appropriate to apply planning strategies that have been developed for suburban or urban centres to rural areas and then anticipate similar outcomes to occur (Hahn, 1970; Daniels et al., 2007). 
Rural communities are less likely than urban areas to have the human capital, financial means, infrastructure, or resources to address the social and economic changes or challenges they encounter (EPA, 2015). A limited financial means and capacity has made sustainability planning difficult for smaller communities to achieve (Zamchevska, 2014). Geographic remoteness, the depletion of natural resources, an aging population, a declining population, and environmental decay are challenges that threaten rural sustainability (Ryan-Nicolls, 2004). Rural and remote communities can be impacted by the decline in farmers, loss of forested land, rapid growth at metropolitan edges, shrinking populations in more remote areas, poor access to jobs and services, a lack of transportation options, and limited community planning capacity (Mishkovsky et al., 2010). It is crucial that approaches to sustainability planning methods are tailored to these diverse needs and characteristics of rural communities (Daniels et al., 2007; Hodge, Hall, \& Robinson, 2017). Over the past decade, and as detailed in the United Nations' 2030 Agenda for Sustainable Development, there is increasing recognition of the importance of rural communities to urban and global welfare, along with the development of a rural-centric sustainability planning praxis (United Nations, 2015).

\section{Place-Based Sustainability Planning for Rural Regions}

For decades rural planning in Canada has addressed a wide range of needs, many of which are related to sustainability. Rural and regional planning efforts have attended to land use issues, labour and employment, demographics, community development, resource management, and ecological protection (Caldwell et al., 2013). Rural planning in Canada has evolved into broader and more comprehensive approaches to sustainability. This was evidenced in the "New Deal for Canadian Cities and Communities," which included support for rural regions to develop Integrated Community Sustainability Plans (ICSPs) that addressed multiple, interconnected dimensions of sustainability. The New Deal, however, was not without pitfalls, one of which was the inability of very small or under-resourced towns and unorganized townships to respond to the opportunity due to limited access to regional planners as well as other economic and social resources. Another pitfall of the ICSP was that, in practice, it did little to promote truly place-based planning (Grant, Beed, \& Manuel, 2018). 
Place-based sustainability planning has the capacity to transform built environments in rural and northern communities and produce positive long-term changes that will impact future generations (Curry and Picketts, 2014). The effective implementation of sustainability planning can promote civic participation, protect the environment, and stimulate the economy (Dalbey, 2008; Emerine et al., 2006). It can effectively be used to reach a community's public health goals and address social determinants of health through strategic planning that mobilizes community assets, implements policies and programs, and improves the built environment (Caldwell et al., 2013; CDC, n.d; Dalbey, 2008). Community planning plays a pivotal role in a community's response to change (Hanna, 2005). It can help a stable economy grow and remain prosperous. It can also help struggling communities overcome hardship and regain their economic position (Emerine et al, 2006). Some research suggests that planning for sustainability in rural regions may benefit from a grounding in and adaption of smart growth approaches (APA, 2012; Dalbey, 2008; Edwards \& Haines, 2007; Naldi et al., 2015; United States Environmental Protection Agency [EPA], 2015, 2016). The following section considers the application of smart growth as a rural planning approach. The section then discusses smart growth's potential applicability in rural and remote Northwestern Ontario, as well as its broader implications for rural regions across the Provincial North.

\section{Smart Growth for Rural and Remote Communities}

The implementation of smart growth can produce healthy, vibrant, and sustainable communities that have equitable and affordable built environments (APA, 2012). This approach to planning encourages healthy behaviours and prompts social and civic participation (Mishovsky et al., 2010; Emerine et al., 2006). Smart growth strategies can create and attract investment opportunities and maintain the identity of a community through the preservation of its unique character.

Smart growth has traditionally focused on urban environments and been oriented towards revitalizing existing infrastructure and reducing urban sprawl (Handy, 2005; Emerine et al., 2006); however, some literature has examined the applicability of smart growth principles outside of metropolitan regions (APA, 2012; Naldi et al., 2015; United States 
Environmental Protection Agency [EPA], 2015). As explained by the American Planning Association in their "Policy Guide on Smart Growth":

Smart growth is not, however, limited to combating the symptoms of sprawl. Rural communities are as essential as urban areas to our national economic health and well-being. Smart Growth principles are applicable to rural ... as well as urban and suburban communities. (APA, 2012, para. 52)

In response to this, and the lack of guidance on the implementation of smart growth in rural regions, the United States Environmental Protection Agency (EPA) (Mishovsky et al., 2010) developed a set of strategies for implementing smart growth in rural communities. This was followed by a framework that involved eleven dimensions for implementing and assessing smart growth strategies in rural communities (EPA, 2015):

I. Revitalize Village and Town Center

II. Strengthen the Local Economy

III. Engage and Connect Community Members

IV. Improve Health and Promote Active Living

V. Protect Natural Habitats and Ecosystems

VI. Support Productive Agriculture for a Variety of Markets

VII. Meet Housing Needs for Different Ages and Incomes

VIII. Preserve Historic and Cultural Resources

IX. Provide Transportation Choices

X. Invest in Efficient Public Infrastructure Systems and Operations

XI. Use Energy Efficiently and Provide Renewable Energy

Each of these dimensions is elaborated on through a number of strategies (specific to each dimension) that planners and local and regional governments can employ to implement and assess rural smart growth activities. The following examines this framework in terms of its applicability to planning for rural towns and townships in Northwest Ontario.

Adapting a Rural Smart Growth Framework for Northwestern Ontario

The framework developed by the EPA (2015) is one of what appears to be only two examples of a smart growth model that is specifically designed for rural regions; Naldi and colleagues (2015) also developed a set of 
indicators for smart rural development, however it was decidedly specific to the European Union and lacked relevance to Canadian contexts. As such, the EPA framework provides an important foundation for beginning to understand the ways in which smart growth might be applied in North America outside of urbanized settings. While the framework's eleven dimensions of rural smart growth are relevant to the rural North, there are also several shortcomings. Since this framework was developed for planners in the United States, and without a northern lens, there are several gaps (additional descriptors and dimensions) from both a Canadian and northern perspective. These are discussed below, identifying options to remedy these gaps before such a framework could be applied in Northwestern Ontario, or more broadly across the Canadian North.

\section{A Northwestern Ontario Perspective on Gaps in Existing Dimensions of the Rural Smart Growth Framework}

The eleven dimensions of rural smart growth proposed by the EPA provide what could be a valuable foundation for planning in rural Northwestern Ontario. All of these dimensions speak to needs outlined by the smart growth panel (2002), Woodrow (2002), and the Growth Plan for Northern Ontario (2011). However, there are some unique needs in the northern Canadian context that could use further elaboration within the existing dimensions. The following discusses four such needs, identified based on existing literature about growth and sustainability in Northwestern Ontario.

The first of these needs relates to Northwestern Ontario's (and much of the Canadian North's) history of and ongoing dependence on natural resource development. While Dimension III of the EPA framework"Strengthen the Local Economy"-includes two strategies aimed at attracting and supporting industry investment, there is no other mention of resource development or support for towns that are or were previously dependent on natural resource industries such as mining and forestry. From a northern perspective, the framework would benefit from inclusion of strategies related to natural resource industries. Strategies could be incorporated into existing dimensions that address the environmental, economic, and social implications of natural resource industries as well as the sustainability of dependence on such industries. Given the historic and 
ongoing significance of these industries in northern geographies, "Natural Resource Use" could potentially be added as a new dimension within the framework.

In the Northwestern Ontario context, another significant gap in the EPA framework is in Dimension VI, "Support Productive Agriculture for a Variety of Markets." This dimension, and the strategies within it, do not include any mention of two very critical and important food system resources in Northwestern Ontario-fisheries and country foods, which include foods acquired through hunting, fishing, trapping, and gathering and are of particular significance for Indigenous peoples in the North as well as for others who depend on food acquisition outside of the formal market system. Fisheries are also a significant resource and significant industry in Northwestern Ontario as well as in many other northern regions. For northern relevance, Dimension VI could be expanded to include these critical aspects of northern, rural food systems.

The third expansion is a revision of Dimension V, "Protect Natural Habitats and Ecosystems." Given the history of environmental impact in the North through natural resource development, and the impending challenges presented by climate change, northern communities must be equipped to respond to prior and future environmental change. The significance of early climate change impacts in the North and the need for planners to prepare for environmental change has been suggested by numerous authorities (Canadian Institute of Planners, 2018; Ministry of the Environment, Conservation and Parks, 2018; Environment North, 2019). This could be an addition to the existing Dimension $V$ but also needs to be woven throughout other dimensions since preparedness for environmental change is necessary across a number of other elements of the framework such as agriculture, housing, and health.

The fourth and final expansion is needed in Dimension IV, "Improve Health and Promote Active Living." Much of Dimension IV is focused on health promotion, particularly supporting access to healthy foods and opportunities for active living, and with much less attention to health care provision. The strategies within this dimension are also decidedly filtered through an American lens, with reference to health insurance that is not relevant in a Canadian context. While universal health coverage is an available resource in Canada, equitable access to health care is a major issue in Northwestern Ontario (Health Quality Ontario, 2017) and throughout 
the Canadian North. From a northern perspective, there is a need for a more decided focus on equitable access to care and on new strategies and technologies (through telemedicine for example) that need more emphasis within the framework. Finally, given the aging demographic in the rural North, there is also a need for consideration of additional strategies to support ageing in place. While seniors' housing and transportation needs are addressed in other dimensions, there is a need to address other needs (such as seniors' healthcare, food security, and community connectedness among others) in Dimension IV and throughout the framework.

\section{Additional Dimensions Required for a Northwestern Ontario Rural Smart Growth Framework}

As discussed above, some of the gaps in the EPA framework can be addressed through expansion of existing dimensions, and strategies within those dimensions. However, there are other gaps for which there is a need for the addition of new dimensions. Beyond the initial eleven proposed in the EPA framework, we suggest adding five additional dimensions as discussed below: Technology and telecommunications; Education; Needs of very rural regions and very isolated communities; Support for inmigration; and Reconciliation and self-determination for First Nations.

\section{Technology and Telecommunications}

In 2013, the Conference Board of Canada published a report outlining the significant inequities in telecommunications infrastructure in northern Canada (Fiser, 2013). Similarly, FedNor's 2018 "Prosperity and Growth Strategy for Northern Ontario" notes the significant need to improve telecommunications, access to technology, and expand technology infrastructure in Northern Ontario. This access is critical in healthcare, employment, community development, and many other sectors. In the European context, Zavratnik et al. (2018) describe the capacity to transform rural smart growth through expansion of the technologically interconnected and digitized "smart village" concept. While in the United States and globally many rural regions have access to up-to-date telecommunication infrastructure and can take advantage of the smart village concept, this is not the case across much of the Canadian North. For applicability within the current Canadian context, the EPA framework 
would need to be expanded with strategies that support and assess the expansion of technology and telecommunications infrastructure.

\section{Education}

Access to secondary and post-secondary education is much more limited in northern, rural communities than in their southern counterparts. The "Annual Report on Ontario's Publicly Funded Schools 2013" (also titled "Mind the Gap") highlights some of the significant inequities in access to educational opportunities for northern Ontario residents (People for Education, 2013). This is an inequity that persists across the North and is particularly acute in remote Indigenous communities (National Collaborating Centre for Aboriginal Health, 2017). As such, there is a need for a dimension that specifically addresses education as an integral part of a rural and northern smart growth framework.

\section{Needs of Very Rural Regions and Very Isolated Communities}

As discussed previously, much of the existing smart growth literature is urban-centric, as are previous planning documents for Northern Ontario and Northwestern Ontario. Similarly, the rural smart growth literature is decidedly focused on the needs of small towns with little consideration given to regions and sub-regions (townships) that lack any definite town or village centres; e.g., the EPA framework has a dimension specifically for town centres and pays little attention to sub-regions that might lack towns or villages. Across Northern Ontario there are numerous townships that lack villages and are comprised entirely of rural households. There are also communities in the North that are isolated in ways not experienced by their southern rural counterparts (i.e., some that are accessible only by air, water, or seasonal gravel and ice roads). In the North, and other very rural regions, there is a need for an additional dimension that can respond to the needs of such very rural, and very remote, communities. Such a dimension could include strategies that assess the effectiveness and attentiveness of regional governance mechanisms to the needs of these communities. Since transportation options are much more limited, as are other municipal infrastructure for water and waste management, there is also a need for strategies that respond to the unique transportation and infrastructure needs of these communities and rural townships. 
Support for In-migration

Supporting in-migration (the process of people moving into a new area of their own country) has become a central aspect of the Growth Plan for Northern Ontario and other examinations of northern development and sustainability (FedNor, 2018). A smart growth framework for rural Northwestern Ontario needs to respond to this, potentially with a dimension focused specifically on supporting and assessing strategies for sustainable in-migration.

Reconciliation and Self-Determination for First Nations

A principal focus of any regional planning activity in Northwestern Ontario should be implementation of the "Truth and Reconciliation Commission of Canada: Calls to Action” (Truth and Reconciliation Canada, 2015). A smart growth framework for rural, northern Canada should include specific attention to work towards reconciliation, supporting equity and self-determination for Indigenous communities. In Northwestern Ontario, this means the addition of a dimension that speaks to the unique strengths and needs of rural and remote First Nations.

\section{Conclusions}

Given the potential applicability of smart growth for rural and northern sustainability planning, there is a possibility that these approaches might hold some relevance for rural Northwestern Ontario, and for other regions across Canada's Provincial North. While the Growth Plan for Northern Ontario (Government of Ontario, 2011) included (to some extent) smart growth principles, it failed to incorporate fundamental values for placebased planning and remained urban-centric in its focus. This article has suggested adapting an existing rural smart growth framework to the specific needs of rural communities in Northwestern Ontario.

In conjunction with the implementation of a rural, northern smart growth framework, there is a need for ongoing engagement of regional governments in rural issues and sustainability planning. Populations in Ontario rural communities are not growing at the same rate as urban centres. As a result, urban centres often receive a greater amount of attention, support, and funding for planning efforts than rural and northern communities. This shift in political power coupled with lack of 
funding will further erode the smallest rural communities-communities that provide critical services to urban centres and in maintaining the ecological integrity of rural landscapes. Collaboration between all levels of government and consistent funding will support the development of healthy, vibrant, and sustainable rural regions.

There is no one-size-fits-all approach to planning for sustainability. Communities in Northwestern Ontario, and across the Provincial North, are not homogenous. The challenges they encounter and the way they respond to challenges and meet their needs will be very different. During sustainability planning processes, it is important that smaller communities consider their unique challenges and diverse needs when setting goals and implementing smart growth or other planning principles. The implementation of a northern-adapted rural smart growth framework can lead to support more effective rural sustainability planning that is reflective of the heterogeneity of communities in Northwestern Ontario. These approaches can ensure that planning will value the importance and unique contributions of rural Northwestern Ontario, while simultaneously fostering economic, social, and ecological resiliency in the region.

\section{Notes}

1. For a definition of rural, we follow a description proposed by Du Plessis and colleagues (3); a definition published by Statistics Canada. They utilize an American classification system for non-metropolitan analysis ("Beale codes"), which they modify ("modified Beale codes") for a Canadian context. The modified Beale codes provide ten distinct categories for metropolitan and non-metropolitan analysis based on the relative weighting of parameters of population size, density, and context and include consideration of the size of a territorial unit: local, community, or regional. In this article we use Codes 6-9 to define "rural" and Code 10 to define "remote." To define "the North" we have included all three territories (Territorial North) as well as the northern administrative regions (NARs) as defined by each provincial government (Provincial North).

2. Since the Canadian Institute of Planners does not provide definitions for planning terminology we are using the definition provided by the American Planning Association (APA), which defines Smart Growth as planning "which supports choice and opportunity by promoting efficient and sustainable land development, incorporates redevelopment patterns that optimize prior infrastructure investments, and consumes less land that 
is otherwise available for agriculture, open space, natural systems, and rural lifestyles" (American Planning Association (APA) 2012, para. 1). The APA also notes that "Smart Growth is not a single tool, but a set of cohesive urban and regional planning principles that can be blended together and melded with unique local and regional conditions to achieve a better development pattern" (American Planning Association (APA) 2012, para. 49).

3. Post-industrial economies are marked by transition away from a manufacturing-based economy, outsourcing of goods production to less industrialized regions, and increased focus on production of services and information. (For discussion within the Canadian context see Krahn, H.J., Lowe, G.S., \& Hughes, K.D. (2008). Work, Industry, and Canadian Society (6th ed.). Toronto: Nelson Education).

4. We define "large" and "small" towns according to Codes 4-5 (large) and 6-7 (small) as defined by Du Plessis, V., Beshiri, R., Bollman, R.D., \& Clemenson, H. (2002). Definitions of "rural". Retrieved from https:// www150.statcan.gc.ca/n1/pub/21-006-x/21-006-x2001003-eng.pdf

5. The Federal Economic Development Initiative for Northern Ontario (FedNor) is a program of the federal government, which aims to support economic development in Northern Ontario

\section{References}

Agyeman,J., \& Angus, B. (2003). The role of civic environmentalism in the pursuit of sustainable communities. Journal of Environmental Planning and Management, 46(3), 345-363.

Alberta Association of Municipal Districts and Counties. (2008). One vision, many voices: How to build a sustainable rural Canada. Retrieved from: http:// www.creativecity.ca/database/files/library/onevision manyvoices.pdf

Alexander, D., \& Jones, B. (2016). Rural sustainability and the "lenses" of place. In Hallstrom, L.K. et al. (Eds.), Sustainability planning and collaboration in rural Canada: Taking the next steps (pp. 25-42). University of Alberta.

American Planning Association. (2012). Policy guide on smart growth. Retrieved from https://www.planning.org/policy/guides/adopted/smartgrowth.htm

Beaulieu, M.S., \& Southcott, C. (2010). North of Superior: An illustrated history of Northwestern Ontario. James Lorimer \& Company.

Calder,M.J., \&Beckie,M.A.(2013). Community engagement and transformation: Case studies in municipal sustainability planning from Alberta, Canada. Community Development, 44(2), 147-160. https://doi.org/10.1080/1557533 $\underline{0.2012 .705868}$ 
Caldwell, W., Kraehling, P., Huff,J., \& Kaptur, S. (2013). Healthy rural communities: Strategies and models. Retrieved from http://www.ruralhealthycommunities. ca/Rural Healthy Communities/Literature Review files/Rural\%20 Communities\%20Lit\%20Review.pdf

Canadian Institute of Planners. (2018). Policy on climate change planning. Retrieved from https:/www.cip-icu.ca/Files/Policy-2018/policy-climateeng-FINAL.aspx

Canadian Mental Health Association [CMHA]. (2009). Rural and northern community issues in mental health. Retrieved from http://ontario.cmha.ca/ public policy/rural-and-northern-community-issues-in-mental-health/\#. V5JGeJOAOko

Canadian Population Health Initiative [CPHI]. (2006). How healthy are rural Canadians? An assessment of their health status and health determinants. Canadian Institute for Health Information. Retrieved from https://secure.cihi. ca/free_products/rural_canadians_2006_report_e.pdf

Canadian Rural Revitalization Foundation [CRRF]. (2015). The state of rural Canada. Retrieved from http://sorc.crrf.ca/

Centre for Disease Control and Prevention [CDC].(n.d).A sustainability planning guide for healthy communities. Retrieved from https://www.cdc.gov/nccdphp/ dch/programs/healthycommunitiesprogram/pdf/sustainability guide.pdf

Cirtwell, C. (2017). Are we thinking about Northern Ontario all wrong? Northern Ontario Business. https://www.northernontariobusiness.com/columns/ are-we-thinking-about-northern-ontario-all-wrong-590981

Curry,J., \& Picketts, I. (2014). Evaluating local sustainability: Planning in northern British Columbia, Canada. International Journal of Sustainable Development and Planning, 9(6), 739-753. https://doi.org/10.2495/SDP-V9-N6-739-753

Dalbey, M. (2008). Implementing smart growth strategies in rural America: Development patterns that support public health goals. Journal of Public Health Management and Practice, 14(3), 238-243. https://doi.org/10.1097/01. PHH.0000316482.65135.e8

Daniels, T.L., Keller, J.W., Lapping, M.B., Daniels, K., \& Segedy, J. (2007). The small town planning handbook (3rd ed). American Planning Association, Planners Press.

Downs, A. (2005). Smart growth: Why we discuss it more than we do it. Journal of the American Planning Association, 71(4), 367-378. https://doi. org $/ 10.1080 / 01944360508976707$

Du Plessis, V., Beshiri, R., Bollman, R.D., \& Clemenson, H. (2002). Definitions of "rural". Retrieved from https://www150.statcan.gc.ca/n1/pub/21-006x/21-006-x2001003-eng.pdf 
Durand, C.P., Andalib, M., Dunton, G.F., Wolch, J., \& Pentz, M.A. (2011). A systematic review of built environment factors related to physical activity and obesity risk: Implications for smart growth urban planning. Obesity Reviews, 12(5), e173-e182. https://doi.org/10.1111/j.1467-789X.2010.00826.x

Edwards, M.M., \& Haines, A. (2007). Evaluating smart growth implications for small communities. Journal of Planning Education and Research, 27(1), 49-64. https://doi.org/10.1177/0739456X07305792

Emerine, D., Shenot, C., Bailey, M.K., Sobel, L., \& Susman, M. (2006). This is smart growth. Retrieved from https://www.epa.gov/sites/production/ files/2014-04/documents/this-is-smart-growth.pdf

Frank, K.I., \& Reiss, S.A. (2014). The rural planning perspective at an opportune time. Journal of PlanningLliterature. https://doi. org/10.1177/0885412214542050

Government of Ontario. (2011). Growth plan for Northern Ontario. Retrieved from https://www.placestogrow.ca/images/pdfs/GPNO-final.pdf

Grant, J.L., Beed, T., \& Manuel, P.M. (2018). Integrated community sustainability planning in Atlantic Canada: Green-washing an infrastructure agenda. Journal of Planning Education and Research, 38(1), 54-66. https://doi. org $/ 10.1177 / 0739456$ X16664788

Hahn, A. J. (1970). Planning in rural areas. Journal of the American Institute of Planners, 36(1), 44-49.

Hallstrom, L.K. et al. (Eds.) (2016). Sustainability planning and collaboration in rural Canada: Taking the next steps. University of Alberta.

Handy, S. (2005). Smart growth and the transportation-land use connection: What does the research tell us? International Regional Science Review, 28(2), 146-167. https://doi.org/10.1177/0160017604273626

Hanna, K.S. (2005). Planning for sustainability: Experiences in two contrasting communities. Journal of the American Planning Association, 71(1), 27-40. https://doi.org/10.1080/01944360508976403

Hodge, G., Hall, H., \& Robinson, I.M. (2017). Planning Canadian regions. UBC Press.

Immigration Northwestern Ontario. (n.d.). About us demographics. Retrieved from http://www.immigrationnorthwesternontario.ca/About Us/Demographics. $\underline{\mathrm{htm}}$

Krahn, H.J., Lowe, G.S., \& Hughes, K.D. (2008). Work, industry, and Canadian society $\left(6^{\text {th }}\right.$ ed.). Nelson Education. 
Longstreth, R.W. (2008). Cultural landscapes: Balancing nature and heritage in preservation practice. University of Minnesota Press.

Mayer, H., \& Knox, P. (2010). Small-town sustainability: Prospects in the second modernity. European Planning Studies, 18(10), 1545-1565.

McManus, P., Walmsley, J., Argent, N., Baum, S., Bourke, L., Martin, J.,Pritchard,B., \& Sorensen, T. (2012). Rural community and rural resilience: What is important to farmers in keeping their country towns alive? Journal of Rural Studies, 28(1), 20-29.

Ministry of the Environment, Conservation and Parks. (2018). Preserving and protecting our environment for future generations: A made-in-Ontario environment plan. Retrieved from https://prod-environmental-registry. s3.amazonaws.com/2018-11/EnvironmentPlan.pdf

Ministry of Northern Development, Mines and Forestry [MNDM]. (2011). An introduction to the growth plan for northern Ontario. Retrieved from https:// www.placestogrow.ca/images/pdfs/GPNO-Introduction-final.pdf

Mishkovsky, N., Dalbey, M., Bertaina, S., Read, A., \& McGalliard, T. (2010). Putting smart growth to work in rural communities. Retrieved from http:// icma.org/en/iceman/knowledgenetwork/documents/kn/Document/301483/ Putting Smart Growth to Work in Rural Communities

Naldi, L., Nilsson, P., Westlund, H., \& Wixe, S. (2015). What is smart rural development? Journal of Rural Studies, 40, 90-101. https://doi.org/10.1016/j. jrurstud.2015.06.006

Nelson, G. (Ed.). (2012). Beyond the global city: Understanding and planning for the diversity of Ontario. McGill-Queen's Press.

Northwestern Health Unit. (2014). COMPASS survey results 2014. Retrieved from https://www.nwhu.on.ca/MediaPressCentre/Documents/Compass\%20 report $\% 202014 \% 20 \mathrm{w} \% 20$ cover-website.pdf

Ontario Chamber of Commerce. (2016). Ontario economic update: Northwest economic region. Retrieved from http://www.occ.ca/wp-content/ uploads/2013/05/Regional-Outlooks Northwest-Economic-Region.pdf

Ontario Professional Planners Institute [OPPI]. (2009). Healthy communities and planning for age friendly communities. Ontario Professional Planners Institute.

People for Education. (2013). Annual report on Ontario's publicly funded schools 2013. Mind the gap: Inequality in Ontario's schools. People for Education. Retrieved from http://education.chiefs-of-ontario.org/upload/documents/ resources/research-reports/reports-education/p4e-mind-the-gap-2013.pdf. Accessed September 102019 
Rody, E. (2016). A guide to the communities in Northwest Ontario. Retrieved from http://www.northernontario.travel/sunset-country/nwo-cities

Ryan-Nicholls, K.D. (2004). Health and sustainability of rural communities. Rural and Remote Health, 4(1), 242.

Scott, K., Park, J., \& Cocklin, C. (2000). From sustainable rural communities' to social sustainability: Giving voice to diversity in Mangakahia Valley, New Zealand. Journal of Rural Studies, 16(4), 433-446.

SmartGrowthBC. (2007). Promoting public health through Smart Growth: Building healthier communities through transportation and land use policies and practices. Retrieved from https://www.cagbc.org/CAGBC/Contacts/ Sign In.aspx?WebsiteKey=7e592978-5927-4a4c-9794-de62b46066648Lo ginRedirect $=$ true $\&$

Statistics Canada. (2017a). Northwest [Economic region], Ontario and Ontario [Province] (table). Census Profile. 2016 Census. Statistics Canada Catalogue no. 98-316-X2016001. Ottawa. Released November 29, 2017. Retrieved from https://www12.statcan.gc.ca/census-recensement/2016/dp-pd/prof/ index.cfm? Lang $=\mathrm{E}$

Statistics Canada. (2017b). Northeast [Economic region], Ontario and Ontario [Province] (table). Census Profile. 2016 Census. Statistics Canada Catalogue no. 98-316-X2016001. Ottawa. Released November 29, 2017. Retrieved from https://www12.statcan.gc.ca/census-recensement/2016/dp-pd/prof/ index.cfm? Lang $=\mathrm{E}$

Statistics Canada. (2017c). Statistics Canada, health regions: Boundaries and correspondence with census geography, (82-402-X). Produced by the Statistical Registers and Geography Division for the Health Statistics Division, 2017. Retrieved from https://www150.statcan.gc.ca/n1/pub/82402-x/2017001/maps-cartes/rm-cr08-eng.htm

Statistics Canada. (2017d). The Aboriginal population in Canada, 2016 Census of Population. Ottawa, Ontario. Data products, 2016 Census. Retrieved from: https://www150.statcan.gc.ca/n1/pub/11-627-m/11-627-m2017027-eng. $\underline{\mathrm{htm}}$

Statistics Canada. (2017e). Focus on geography series, 2016 Census. Statistics Canada Catalogue no. 98-404-X2016001. Ottawa, Ontario. Data products, 2016 Census. Retrieved from https://www12.statcan.gc.ca/censusrecensement/2016/as-sa/fogs-spg/Facts-PR-Eng.cfm?TOPIC=9\&LANG= Eng\&GK=PR\&GC $=35$

Truth and Reconciliation Canada. (2015). Honouring the truth, reconciling for the future: Summary of the final report of the Truth and Reconciliation Commission of Canada. Truth and Reconciliation Commission of Canada. 
United Nations General Assembly. (2015). Transforming our world: The 2030 agenda for sustainable development. General Assembly, 70th Session.

United States Environmental Protection Agency [EPA]. (2016). Framewwork for creating a smart growth economic development strategy: A tool for small cities and towns. Retrieved from https://www.epa.gov/sites/production/files/2016-01/ documents/small town econ dev tool 010516.pdf

United States Environmental Protection Agency [EPA]. (2015). How small towns and cities can use local assets to rebuild their economies: Lessons from successful places. Retrieved from https://www.epa.gov/smartgrowth/ how-small-towns-and-cities-can-use-local-assets-rebuild-their-economies

Visvaldis, V., Ainhoa, G., \& Ralfs, P. (2013). Selecting indicators for sustainable development of small towns: The case of Valmiera municipality. Procedia Computer Science, 26, 21-32.https://doi.org/10.1016/j.procs.2013.12.004

Woodrow, M. (2002). Challenges to sustainability in Northern Ontario. Institute of the Environment, University of Ottawa. Retrieved from http://docs. assets.eco.on.ca/reports/other-publications/2002/2002-Challenges-toSustainability-in-Northern-Ontario.pdf

Woods, M. (2005). Rural Geography: Processes, responses and experiences in rural restructuring. Sage.

Ye, L., Mandpe, S., \& Meyer, P.B. (2005). What is "smart growth?"-Really? Journal of Planning Literature, 19(3), 301-315.

Yousefian, A., Hennessy, E., Umstattd, M.R., Economos, C.D., Hallam, J.S., Hyatt, R.R, \& Hartley, D. (2010) Development of the rural active living assessment tools: Measuring rural environments. Preventive Medicine, 50(S1), S86-S92. https://doi.org/10.1016/j.ypmed.2009.08.018

Zamchevska, V. (2014). Strengthening sustainability assessment in town planning in rural Saskatchewan. Retrieved from http://ecommons.usask.ca/bitstream/ handle/10388/ETD-2014-02-1417/ZAMCHEVSKA-THESIS. pdf?sequence $=5$

Zavratnik, V., Kos, A., \& Stojmenova Duh, E. (2018). Smart villages: Comprehensive review of initiatives and practices. Sustainability, 10(7), 2559. https://doi.org/10.3390/su10072559

\section{Author}

Rebecca Schiff is associate professor in the Department of Health Sciences at Lakehead University in Thunder Bay, Ontario. 